\title{
Fried potatoes: Impact of prolonged frying in monounsaturated oils
}

\author{
Carla S.P. Santos ${ }^{\mathrm{a}}$, Lucía Molina-Garcia ${ }^{\mathrm{a}, \mathrm{b}}$, Sara C. Cunha ${ }^{\mathrm{a}}$, Susana Casal ${ }^{\mathrm{a}, \mathrm{c}, *}$ \\ a REQUIMTE, Laboratory of Bromatology and Hydrology, Faculty of Pharmacy, University of Porto, Rua Jorge de Viterbo Ferreira 228, 4050-313 Porto, Portugal \\ ${ }^{\mathrm{b}}$ Department of Physical and Analytical Chemistry, Faculty of Experimental Sciences, University of Jaén, Campus las Lagunillas, E-23071 Jaén, Spain \\ c EPIUnit - Instituto de Saúde Pública, Universidade do Porto, Rua das Taipas, $n^{\circ} 135$, 4050-600 Porto, Portugal
}

\section{A R T I C L E I N F O}

Keywords:
Deep-frying
White potatoes
Nutritional and sensory quality
Acrylamide
Ascorbic acid
Oxidation
Monounsaturated fats

\begin{abstract}
A B S T R A C T
Fresh potatoes were intermittently deep-fried up to recommended limits $\left(175^{\circ} \mathrm{C}, 8 \mathrm{~h} / \mathrm{day}, 28 \mathrm{~h}\right)$ in extra-virgin olive oil (EVOO), peanut oil (PO) and canola oil (CO), and compared for diverse chemical components and sensorial attributes, aiming to quantify the impact of prolonged frying on potatoes nutrients, and the potential alterations resulting from the use of different monounsaturated-rich oils.

Independently of oil type, its degradation promotes time-dependent losses of important potato nutrients, as vitamin C. Regarding the monounsaturated-rich oils tested, potatoes fried in CO had more equilibrated fatty acid profiles, but higher amounts of aldehydes derived from PUFA oxidation, while in EVOO were enriched with phenolic compounds. Acrylamide amounts were not affected by oil type or frying hours. Sensory degradation was gradually perceived by the panellists, except in PO.

Prolonged frying should not be studied only on the basis of oil degradation because, even if within regulated limits, it induces loss of important food compounds.
\end{abstract}

\section{Introduction}

Deep-frying is among the most popular cooking methods worldwide. Several studies comparing performances of different vegetable oils during prolonged frying are found in the literature, as recently reviewed (Hosseini, Ghorbani, Meshginfar, \& Mahoonak, 2016; Nayak, Dash, Rayaguru, \& Krishnan, 2016), but when searching for the nutritional impact from the consumer's perspective, on the fried food, data on nutritional and sensory changes during prolonged frying are scarce (Boskou, Salta, Chiou, Troullidou, \& Andrikopoulos, 2006; Carlson \& Tabacchi, 1986; Han, Kozukue, Young, Lee, \& Friedman, 2004; Romano, Giordano, Vitiello, Grottaglie, \& Musso, 2012; Salta, Kalogeropoulos, Karavanou, \& Andrikopoulos, 2008; Zhang, Zhang, Cheng, Wang, \& Qian, 2015). Fried food incorporates fat in variable amounts, while being enriched in oil components, as fatty acids and vitamin E (Casal, Malheiro, Sendas, Oliveira, \& Pereira, 2010; Chiou, Kalogeropoulos, Boskou, \& Salta, 2012). Simultaneously, some food components are loss by evaporation or leaching, as moisture itself, or degraded, as ascorbic acid, while new compounds are formed during these hot oil-food interactions, including highly pleasant ones, as the typical fried volatile flavors, or unhealthy ones, as degraded lipids and acrylamide (Camire, Kubow, \& Donnelly, 2009).

Potatoes (Solanum tuberosum L.) are regarded as an excellent source of carbohydrates, supply protein of high relative biological value
(90-100), while being very low in fat $(0.1 \%)$ (Camire et al., 2009). They are also rich in several micronutrients, as essential minerals, carotenoids, phenolic compounds, and vitamin C (Camire et al., 2009). However, to increasing its digestibility, potatoes are consumed only after cooking, by boiling, roasting, frying, among others (Decker \& Ferruzzi, 2013). Therefore, together with the agronomic practices, postharvest storage methods and potato varieties, known to influence potatoes composition, the cooking method and, in the particular case of frying, the cooking oil determines the nutrients truly available to consumers.

From the vegetable oil perspective, many types of vegetable oils are available for deep-frying purposes, highly based on availability, tradition, and thermal resistance. Soybean and sunflower are more generally accepted worldwide, canola oil is common in various European countries and Canada, peanut oil is also used in several countries, while olive oil is more traditionally used around the Mediterranean Sea (Hosseini et al., 2016). While the health impact of saturated fats is still under discussion, and hydrogenated ones are fading out, vegetable unsaturated fats have moved to the forefront, and among them, monounsaturated fats (MUFA) are increasingly providing a broader spectrum of functionality and health benefits (Gillingham, HarrisJanz, \& Jones, 2011), with an inherent higher thermal oxidation stability than polyunsaturated fats (PUFA). Several "high-oleic" vegetable oils, both natural (as olive oil and peanut oil) or "modified" (high-oleic

\footnotetext{
* Corresponding author at: Laboratory of Bromatology and Hydrology, Faculty of Pharmacy, University of Porto, Rua Jorge de Viterbo Ferreira 228, 4050-313 Porto, Portugal.

E-mail addresses: csps.santos@gmail.com (C.S.P. Santos), lucymolgar@gmail.com (L. Molina-Garcia), sara.cunha@ff.up.pt (S.C. Cunha), sucasal@ff.up.pt (S. Casal).
} 
rapeseed (canola), high-oleic sunflower, high-oleic soybean, or palmolein fractions), are increasingly available. As stated above, a huge amount of research has been dedicated to the comparative performance of different frying oils, but most studies are strictly focused on oil degradation and lipid absorption, without evaluating the true impact on potatoes quality. Those who do, evaluate potatoes quality for single compounds and not as a global nutritional approach (Boskou et al., 2006; Carlson \& Tabacchi, 1986; Han et al., 2004; Romano et al., 2012; Salta et al., 2008; Zhang et al., 2015).

Therefore, the aim of the present work was to compare the nutritional and sensory quality of fresh potatoes during intermittent deepfrying, in three MUFA-rich oils commercially available to consumers: peanut oil (PO), canola (CO) and extra virgin olive oil (EVOO), up to oil recommended disposal point ( $25 \%$ of total polar compounds - TPC). The main focus is the nutritional, sensory, and potential health impacts of the degraded fat interacting with potato bioactive compounds, while attempting to compare the gains and losses from using different monounsaturated-rich oils.

\section{Materials and methods}

\subsection{Frying assays}

White potatoes (Solanum tuberosum L., Fontane variety) were chosen due to their frying aptitude and availability in the local market (Porto, Portugal). Their proximal composition included $1.2 \mathrm{~g}$ of sugars, $0.1 \mathrm{~g}$ of lipids and $1.6 \mathrm{~g}$ of fiber, all on a $100 \mathrm{~g}$ fresh basis, further detailed in Table 1. EVOO and PO were commercially available in Portugal, while $\mathrm{CO}$ was acquired in France.

The present work was designed to simulate restaurant frying, heating the oils for $8 \mathrm{~h}$ a day (intermittent thermal stress $-8 \mathrm{~h}$ heating and $16 \mathrm{~h}$ cooling), with frying cycles every $30 \mathrm{~min}$. Deep-frying assays were performed in three deep-fat electric fryers (TRISTAR, FR-6929 model, The Netherlands), at $175{ }^{\circ} \mathrm{C}$ (periodically controlled with a calibrated digital thermometer), using $1.5 \mathrm{~L}$ of oil on each, without reposition. Fresh potatoes were cut into toothpicks $(1 \times 1 \times 4 \mathrm{~cm})$, washed, drained, and a batch (50 g) was fried during $6 \mathrm{~min}$, every $30 \mathrm{~min}$, during $8 \mathrm{~h}$ per day, up to $28 \mathrm{~h}$, imposed by the total polar compounds content in PO and CO (> 25\%), based on dielectric readings oil (Food Oil Sensor, Switzerland).

Potatoes samples were collected in triplicate every $4 \mathrm{~h}$, except on the first day (first sampling at $8 \mathrm{~h}$ ). Some analyses were immediately executed, namely sensory analysis, instrumental color, moisture and total ascorbic acid. The remaining portions were stored at $-20{ }^{\circ} \mathrm{C}$ until further analyses. Fresh vegetable oils were also analyzed for some compositional parameters.

\subsection{Chemical analysis}

\subsubsection{Moisture}

Moisture was determined after grinding, by infrared drying at $105{ }^{\circ} \mathrm{C}$ (Scaltec SMO 01, Germany), until constant weight, being expressed in $\mathrm{g}$ per $100 \mathrm{~g}$ of raw or fried potatoes.

\subsubsection{Lipid content}

Incorporated fat was extracted with petroleum ether $\left(40-60{ }^{\circ} \mathrm{C}\right.$; $0.01 \%$ BHT) using an automatic Soxhlet device (Büchi Extraction System, B-811). Lipids were dried under vacuum before weighting, and stored at $4{ }^{\circ} \mathrm{C}$.

\subsubsection{Fatty acids composition}

Fatty acids composition of lipid extracts and fresh vegetable oils was evaluated by gas chromatography, after cold transmethylation (ISO 12966-2:2011, 2011), using a FAME CP-Select CB column $(50 \mathrm{~m} \times 0.25 \mathrm{~mm})$ on a Chrompack CP 9001 gas chromatograph (Chrompack, Middelburg, The Netherlands). Fatty acids identification and FID calibration was accomplished with a certified reference mixture of fatty acids methyl esters (TraceCert - Supelco 37 component FAME mix, USA). Fatty acids were expressed in $\mathrm{g}$ per $100 \mathrm{~g}$ of potatoes or vegetable oils.

\subsubsection{Tocopherols}

Tocopherols of potato lipid extracts and fresh vegetable oils were quantified by normal-phase HPLC with fluorescence detection, using tocol (Matreya, USA) as internal standard and direct dilution in hexane (Casal et al., 2010). Individual calibration curves were prepared for each identified tocopherol compound (Sigma-Aldrich, Germany). Results were expressed in $\mu \mathrm{g} / 100 \mathrm{~g}$ for potatoes or $\mathrm{mg} / 100 \mathrm{~g}$ for oils, with a quantification limit of $0.2 \mu \mathrm{g} / 100 \mathrm{~g}$.

\subsubsection{Ascorbic acid}

Total ascorbic acid extraction was carried out according to Santos, Cunha, and Casal (2017), using an aqueous solution with $8 \%$ acetic acid and $3 \%$ metaphosphoric acid, together with tris-(2-carboxy-ethyl)phosphine-hydrochloride (2.5 mM) (Carl Roth, Germany) for dehydroascorbic acid reduction, under light protection. Chromatographic analyses were performed using a HPLC system (Gilson, France), with a photodiode array detector (Varian Prostar, USA), controlled by a data processor software (Varian Star Workstation, USA). Chromatographic separation was achieved using a reversed-phase C18 Spherisorb ODS-2 column (Waters, $3 \mu \mathrm{m}, 150 \times 4.6 \mathrm{~mm}$, Ireland) with a gradient of acetate buffer $(30 \mathrm{mM})$ and aqueous methanol $(30 / 70 \mathrm{v} / \mathrm{v})$, at $0.6 \mathrm{~mL} /$ min. Quantification was based on external standard method using Lascorbic acid standard (Sigma-Aldrich, USA), subjected to the entire extraction procedure, with a quantification limit of $5 \mu \mathrm{g} / \mathrm{mL}$ of extract.

\subsubsection{Total carotenoids}

Total carotenoids of both potatoes and fresh vegetable oils were estimated by UV absorbance according to Nagata and Yamashita (1992), after extraction with acetone:hexane (40:60), being expressed in $\mu \mathrm{g}$ of $\beta$-carotene equivalents per $100 \mathrm{~g}$ of potatoes or oils.

\subsubsection{Antioxidant activity}

Sample extracts were prepared according to Pérez-Jiménez et al. (2008). For potatoes, extracts were prepared with acidic methanol/ water extraction, followed by acetone/water, while the fresh vegetable oils were directly diluted in ethyl acetate.

Total reducing capacity, as a broad estimation of total phenolics, was determined by the colorimetric Folin-Ciocalteu method (Wu et al., 2012) adapted to 96-well microplates. For the radical scavenging activity, extracts were analyzed for their capacity to scavenge the stable 2,2-diphenyl-1-picrylhydrazyl (DPPH) radical (Wu et al., 2012). The $\beta$ carotene/linoleic acid bleaching assay was also applied to the extracts (Fukumoto \& Mazza, 2000). Gallic acid (Sigma-Aldrich, USA) was used as reference on all the assays, within the $0.125-50 \mu \mathrm{g} / \mathrm{mL}$ range $\left(\mathrm{R}^{2}>0.998\right)$, with the results expressed in $\mathrm{mg}$ of gallic acid equivalents (GAE) per $100 \mathrm{~g}$ of potatoes or oils.

\subsubsection{Acrylamide}

Acrylamide content of potatoes was analyzed by GC-MS in selected ion monitoring mode, after extraction with water and 1,2-dichloroetane and derivatization with xanthydrol, as detailed in Molina-Garcia et al. (2015), with a quantification limit of $1 \mu \mathrm{g} / 100 \mathrm{~g}$.

\subsubsection{Volatile compounds}

Potatoes volatile compounds were analyzed by headspace solidphase micro extraction (HS-SPME) coupled with GC-MS (Agilent, Little Falls, DE, USA), based on a previously developed protocol (MolinaGarcia, Santos, Cunha, Casal, \& Fernandes 2017), with slight adaptations and validation for the potato matrix. Two internal standards (4methyl-2-pentanol and 1,2,3-trichloropropane, Sigma, USA, $0.2 \mu \mathrm{g}$ each from ethanol solutions) were added to an accurate amount of potatoes 


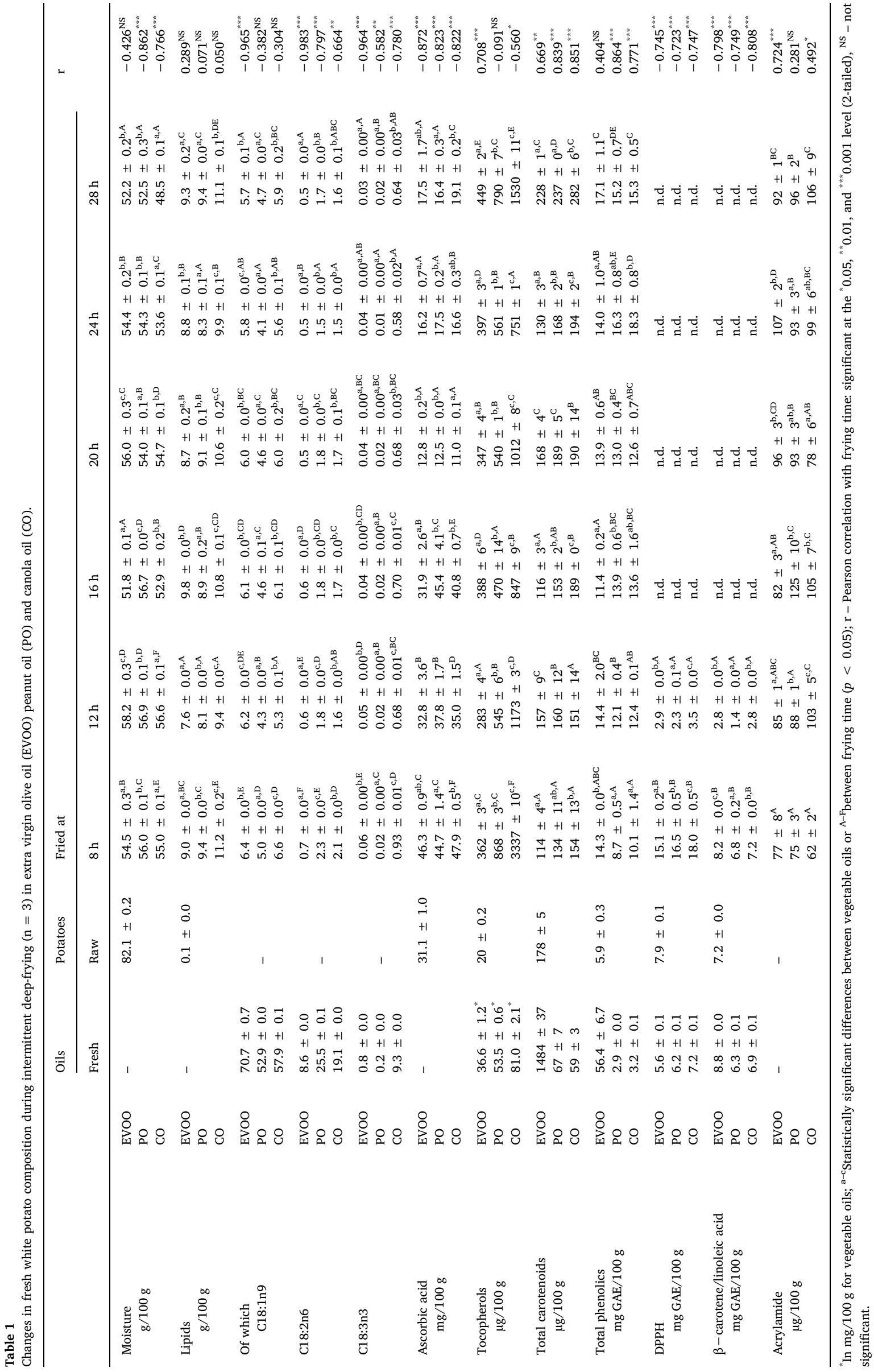


mass (1.5 g), followed by $7 \mathrm{~mL}$ of $\mathrm{NaCl}$ aq. solution (15\%), and stabilized at $65{ }^{\circ} \mathrm{C}$ during $5 \mathrm{~min}$ (glass stir-bar, $400 \mathrm{rpm}$ ). A manual SPME holder exposed the fiber (DVB/CAR/PDMS 50/30 $\mu \mathrm{m}$ film thickness; Supelco; USA) to the headspace for $30 \mathrm{~min}$. Volatiles were thermally desorbed for $5 \mathrm{~min}$ in the injector port (splitless mode; $270{ }^{\circ} \mathrm{C}$ ) of the GC-EI-MS system. Chromatographic separation was performed on a fused-silica SPB-5 Capillary GC column $(60 \mathrm{~m} \times 0.32 \mathrm{~mm}$ I.D. $\times 1 \mu \mathrm{m}$ film thickness, Supelco) with a temperature programmed from $40{ }^{\circ} \mathrm{C}$ to $240{ }^{\circ} \mathrm{C}$, with a total run time of $45 \mathrm{~min}$. The MS transfer line and ion source were at $250{ }^{\circ} \mathrm{C}$, and MS quadrupole temperature at $200{ }^{\circ} \mathrm{C}$, with electron ionization of $70 \mathrm{eV}$; set in full scan mode $(\mathrm{m} / z 20$ to 450 at 2 scan/s). Compounds were identified by comparing the respective mass spectra with a mass spectral database (WILEY7 n.L), and semiquantification achieved as internal standard equivalents from their peak area ratios, express in $\mu \mathrm{g}$ of internal standard equivalents per $100 \mathrm{~g}$ of potatoes or oils. The non-aldehyde compounds evaluated comprise alkanes, alkenes, alkylbenzenes, ketones, carboxylic acids, furan derivatives, pyrazines, pyridine, pyrimidine, and pyrrole, while aldehyde include alkanals, alkenals, and alkadienals.

\subsection{Color}

Potatoes color was measured directly in the surface on three different locations. A Minolta CR-400 colorimeter (Konica Minolta Optics Inc., Japan) with illuminant D65 was used. The color space system used was CIE-L*a* $\mathrm{b}^{*}$ to represent color coordinate values. $\mathrm{L}^{*}$ value represents lightness-darkness dimension (0-100), $\mathrm{a}^{*}$ value represents red-green dimension $(-120$ to 120$)$, and $b^{*}$ value represents yellow-blue dimension ( -120 to 120$)$. Color change $(\Delta \mathrm{E})$ between raw and fried potatoes was calculated according to the following equation: $\Delta \mathrm{E}=\sqrt{\Delta \mathrm{L}^{*^{2}}+\Delta \mathrm{a}^{* 2}+\Delta \mathrm{b}^{* 2}}$. Browning index was also calculated as $\mathrm{BI}=[100(x-0.31)] / 0.172, \quad$ where $\quad x=(a+1.75 L) /(5.645 L$ $+a-3.012 b)$, in accordance with Yost, Abu-Ali, and Barringer (2006).

\subsection{Sensory analysis}

Quantitative descriptive analysis was conducted to assess potatoes quality during consecutive days of deep-frying with an unstructured scale line of 10-cm (Troncoso, Pedreschi, \& Zíñiga, 2009). Twelve assessors (10 females and 2 males with age range of 23-55) of the Faculty of Pharmacy of University of Porto constituted the panel. The assessors were trained in three pre-sessions, with potatoes fried in fresh and used oils. Throughout the sessions, samples were identified with random letters and water was provided for assessors to clean their palates between samples. The attributes were evaluated individually by the following order: appearance, smell, first bite and then further chew the product, and finally assess sensations after swallowing. In the end of each training session, the answers were analyzed collectively, and data were assessed to determine the need of additional training.

Finally, the sensory analyses were performed 3-5 min after removing samples from the fryers, while still hot. One evaluation session was performed at mid-afternoon, on three consecutive days. Samples at $28 \mathrm{~h}$ of frying were not given to the panel. Three samples, in individual white plates marked with three random digits, and water, were presented to the assessors, and the analysis took place as described above.

\subsection{Statistical analysis}

All analytical determinations were performed at least in triplicate, and results were expressed as mean and standard deviation.

Significant differences, between vegetable oils or frying time, were analyzed using a one-way ANOVA (parametric test) or a Kruskal-Wallis (non-parametric test). Between two samples, a $t$-Test was applied for means comparison. Moreover, Pearson's and Spearman's correlations were established between parameters, if normal distribution was verified or not, respectively.

The statistical tests were performed using XLSTAT 2016 with statistical significance set at $p<0.05$.

\section{Results and discussion}

The nutritional and sensory quality of fried potatoes is associated with diverse chemical (moisture and fat contents), physical (color), and structural (crispiness attribute) parameters (Pedreschi, 2012). Thus, each of these parameters is discussed in detail below. Frying assays were kept up to $28 \mathrm{~h}$, when EVOO reached $25 \%$ TPC, while PO and CO had already reached it at $23 \mathrm{~h}$ and $24 \mathrm{~h}$, respectively.

\subsection{Impact of prolonged frying in monounsaturated-rich oils on nutritional quality of fresh white potatoes}

Potatoes moisture reduced from $82.1 \%$ (Table 1 ), within the characteristic range of potatoes with frying aptitude (Pedreschi, 2012), to 48.5-58.2\%, corresponding almost to a duplication of the dry mass amount of potato on a $100 \mathrm{~g}$ basis, and therefore an expected enrichment on all potatoes components. Regarding the three oils tested, despite the significant differences observed for some frying time $(p<0.05)$, no clear pattern was perceived. However, an apparent small moisture reduction was observed with time, with the lowest moisture contents observed at $28 \mathrm{~h}$ for all samples $(p<0.05)$, with strong negative Pearson correlations for PO $(\mathrm{r}=-0.862, p<0.001)$ and $\mathrm{CO}(\mathrm{r}=-0.766, p<0.01)$. This could be derived from achieving a higher degree of doneness over time. With all processing condition constant over time, it could be a consequence of oil degradation, known to influence several physical properties that influence its thermal efficiency, as surface tension or convective heat transfer coefficients (Tseng, Moreira, \& Sun, 1996). The decreased oil:potato ratio over time, imposed by the absence of replenishment, could also have contributed for this effect.

Moisture reduction was inevitably accompanied by fat absorption, with final contents ranging from 7.6 to $11.2 \%$ (Table 1 ), but no correlations with frying time were observed, with similar fat amounts at the first $(8 \mathrm{~h})$ and last $(28 \mathrm{~h})$ samplings. Indeed, previous authors have demonstrated that one of the most significant parameters conditioning oil absorption in potatoes frying is temperature (Pedreschi, 2012), kept constant during all the assays. However, significant $(p<0.05)$ differences were observed with $\mathrm{CO}$, exhibiting slightly higher lipid amounts at all samplings ( $+0.8 \%$ to $+2.2 \%$ ), therefore not associated with oil degradation. Some authors have studied the influence of oil type on fat uptake, but the results are not consistent, nor the mechanism proposed for the differences observed (Kita \& Lisinska, 2005). Again, inherent characteristic of the oils, as fatty acid composition, viscosity, and specific heat characteristics (Ziaiifar, Achir, Courtois, Trezzani, \& Trystra, 2008) (not evaluated), have been associated with oil absorption. Therefore, this could be a specific characteristic of the oil brand used and, to clarify it, different brands of the three oils could have been used simultaneously. Both moisture and fat content were similar to those of French fries from different varieties and fried in diverse vegetable oils (Salta et al., 2008).

Due to the reduced amounts of raw potatoes lipids $(0.1 \%$ - Table 1$)$, the main fatty acids after processing reflect directly the frying oil composition (Table 1), as expected (Hosseini et al., 2016). Based on the high content of MUFA on the three oils, oleic acid was consistently the major one on all potato samples (Table 1), slightly lower when fried in PO (4.1-5.2 g/100 g), than EVOO (5.7-6.4 g/100 g) or CO (5.3-6.6 g/ $100 \mathrm{~g}$ ), with strong negative Pearson correlations with frying time for EVOO ( $\mathrm{r}=-0.965, p<0.001)$. The polyunsaturated fatty acids reduced with increased frying time, as observed, for instance, by the strong negative Pearson correlations with frying time for C18:2n-6/ C16:0 ratio (EVOO: $r=-0.980$, PO: $r=-0.961$, CO: $r=-0.949$, all 


\section{Trans fatty acids}

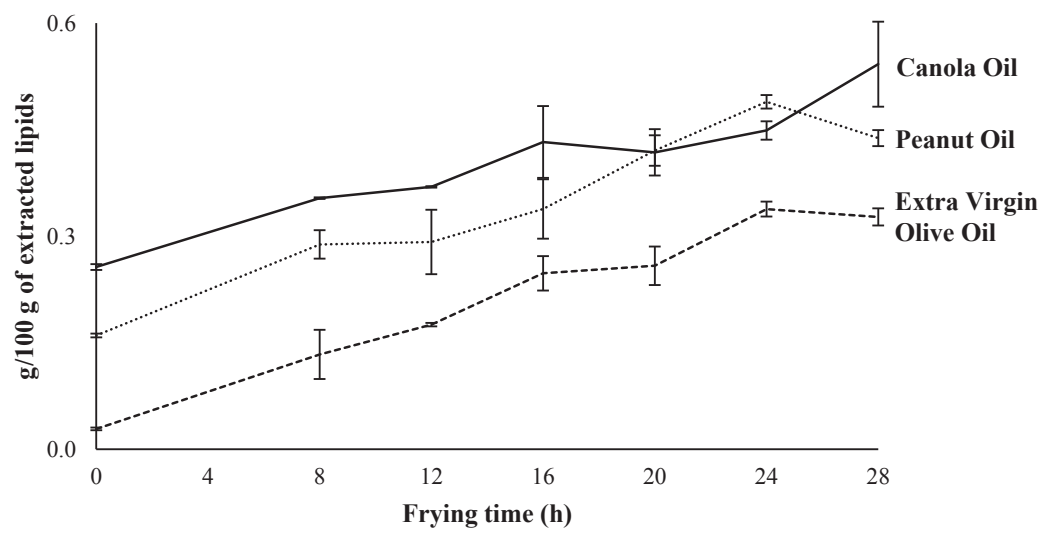

Fig. 1. Changes of trans fatty acids during intermittent fresh white potatoes deep-frying for Extra Virgin Olive Oil (----), Peanut Oil (-.....), and Canola Oil $(-)(\mathrm{n}=3)$. at $p<0.001$ ), indicative of fatty acid oxidation. Linolenic acid (C18:2n-6), present in higher amounts in CO, reduced slightly with frying time (Table 1). Regarding trans fatty acids (TFA), also common indicators of oil thermal degradation, despite being generally low on all potato extracts (below $0.6 \%$ in the extracted lipids) (Fig. 1), the amounts increased consistently with frying time $(p<0.05)$, retaining the differences already observed on the fresh oils (Table 1), with potatoes fried in EVOO having lower TFA content, while potatoes fried in CO had significantly higher amounts $(p<0.05)$, closely followed by PO. These results were corroborated by strong positive Pearson correlations between TFA and frying time on the three oils (EVOO: $r=0.965$, PO: $r=0.927$, CO: $r=0.898$, all at $p<0.001$ ), in accordance with published data for palm superolein and olive oil during $48 \mathrm{~h}$ (Romano et al., 2012).

Despite the high frying temperature, the food temperature is not known to exceed $100{ }^{\circ} \mathrm{C}$, and cooking takes place in a short time, with expected small nutritional losses compared to other confection methods (Decker \& Ferruzzi, 2013). Indeed, most studies on prolonged frying compare oils degradation over time, inferring that the absorption of degraded oil, instead of fresh one, will compromise only the potatoes lipid content and composition. Without being false, this is just part of the problem, as most of these degraded compounds are not chemically stable, and will interact with potatoes' most sensitive components, as vitamins and antioxidants, potentiating degradation beyond the expected. This is particularly true for ascorbic acid. Potatoes are rich sources of ascorbic acid in our diet (Camire et al., 2009), but it is partially loss during the thermal and oxidative stress imposed by food processing. As showed from Table 1, the $31 \mathrm{mg} / 100 \mathrm{~g}$ of ascorbic acid present in fresh potato reduced drastically with frying time. The apparent increase at $8 \mathrm{~h}$ of frying, observed on the three oils, was not sufficient to compensate moisture decrease, indicating already a great percentage of loss in the first frying hours. From this point forward frying induced higher ascorbic acid losses, indicating that the frying oil is under a higher oxidative stress, and its degradation compounds, namely free radicals, interact with potatoes ascorbic acid (Carlson \& Tabacchi, 1986; Han et al., 2004). Strong negative Pearson confirm these increased ascorbic acid losses with time (EVOO: $\mathrm{r}=-0.872$; PO: $\mathrm{r}=-0.823$; CO: $\mathrm{r}=-0.822$, all at $p<0.001$ ). In this case, no differences were observed between the tested oils.

For total free carotenoids, present on fresh potatoes and oils (particularly in EVOO) (Table 1), a slight decrease was observed in the first samplings (8-12 h), followed by a full recovery on the last sampling hours, with positive Pearson correlation in the potatoes fried in the three oils (EVOO: $\mathrm{r}=0.669, p<0.01$; PO: $\mathrm{r}=0.839, p<0.001$; CO: $r=0.851, p<0.001)$. It is interesting to denote that, despite the huge differences observed in the fresh oils, with 20 times higher carotenoids in EVOO than PO or CO, no differences were observed between fried potatoes, even if the different amounts of incorporated lipids are taken into account. This apparent carotenoids stability is consistent with the data from Blessington et al. (2010), and the increased pattern with time can be supported by moisture loss, also higher at $28 \mathrm{~h}$, together with possible partial hydrolysis of carotenoids bonded to potatoes compounds (Burmeister et al., 2011), without excluding the possibility of contribution from coloured Maillard reaction products. However, no distinction was made between xanthophylls and carotenes, both present in the potatoes and oils, whose balance might alter during processing and influence total carotenoids content and profile (Burmeister et al., 2011).

Regarding tocochromanols, collective known as vitamin E, they are present in very low amounts in raw potatoes $(20 \mu \mathrm{g} / 100 \mathrm{~g}$ of $\alpha$-tocopherol). The higher amounts after frying are proportional to the amount of lipids incorporated and the composition of each vegetable oil (Hosseini et al., 2016) (Table 1), with higher amounts in CO, followed by PO and EVOO $(p<0.05)$. This pattern was kept up to the last sampling hour, with potatoes fried in $\mathrm{CO}$ having higher tocopherol amounts and EVOO lower $(p<0.05)$. However, with increased frying time, different patterns were observed, with a slight but significant increase when fried on EVOO ( $\mathrm{r}=0.708, p<0.001)$, a significant decrease in $\mathrm{CO}(\mathrm{r}=-0.560, p<0.05)$, and non-significant variations with PO. This is indicative of a higher preservation of vitamin $\mathrm{E}$ during EVOO frying. The apparent increase over the last sampling could be just a direct consequence of the higher lipids amounts observed, as previously discussed.

Regarding phenolic compounds, again present on both potatoes and vegetable oils, particularly in EVOO, their content on the fried potatoes increased in comparison with the raw ones on all samplings, more than doubling the initial amounts, as expected from moisture loss. Indeed, on a dry basis, from an initial $33 \mathrm{mg} / 100 \mathrm{~g}$ in raw potato, potatoes fried in PO heated for $28 \mathrm{~h}$ kept $32 \mathrm{mg} / 100 \mathrm{~g}$ and CO kept $30 \mathrm{mg} / 100 \mathrm{~g}$, indicative of high stability. Despite the recognized loss of oil phenolic compounds with frying time (Casal et al., 2010), with EVOO heated for $28 \mathrm{~h}$ the potatoes were still being enriched in phenolic compounds, with $36 \mathrm{mg} / 100 \mathrm{~g}$, on a dry basis. When compared with the literature, a huge variation of total phenolic amounts is found, particularly derived from their estimation being based on the reaction with the Folin-Ciocalteu reagent, as in the present article, and also from the standard phenolic used as references, usually chlorogenic, caffeic or gallic acids. However, frying is known to be conservative regarding these compounds (Blessington et al., 2010), where with the confirmation that this protective effect seems to be prolonged even with heavily degraded oil.

Regarding the antioxidant activity of the fried potatoes, two different methods were tested: the capacity to inhibit oxidation of $\beta$-carotene by reactive oxygen species released from oxidized linoleic acid, and the capacity to release electrons for inhibition of radicals. Both potato compounds (ascorbic acid, phenolic compounds, carotenoids, etc.) and vegetable oil compounds (phenolics, carotenoids, 
tocochromanols, phytosterols, etc.) are expected to contribute for the collective antioxidant activity observed with these assays. Although without major differences between the three fresh oils with both assays, potatoes sampled at $8 \mathrm{~h}$ showed differences in their antioxidant activity, with higher activity with the DPPH assay with CO fried potatoes, and higher $\beta$-carotene/linoleic acid bleaching activity in EVOO. However, on both assays the antioxidant activity was below the quantification limit from the $16 \mathrm{~h}$ forward, contradicting the expected antioxidant capacity derived from the presence of antioxidants on the potatoes, namely ascorbic acid, carotenoids and phenolic compounds. This could occur because the tests were made with potatoes extracts where the degraded oil is in contact with potato bioactive compounds, and might compete for the antioxidant capacity of the potato compounds during the assay, being therefore not available to react with the DPPH radical or to counteract with the ROS released from linoleic acid. This is particularly interesting from the nutritional point of view, showing that, despite the presence of interesting bioactive compounds in the fried food, as carotenoids and phenolic compounds, the total balance of effects will be potentially ineffective in our body, or even potential pro-oxidative.

\subsection{Impact of prolonged frying in monounsaturated-rich oils on acrylamide of fresh white potatoes}

As a possible carcinogenic in humans (Group 2A), this compound has received much attention from the scientific community and consumers in general, with fried potatoes positioned among the highest sources (Matthäus \& Haase, 2014).

Raw potatoes acrylamide contents were below the quantification limit $(1 \mu \mathrm{g} / 100 \mathrm{~g})$, as expected because its formation occurs when they are cooked at high temperature $\left(>120^{\circ} \mathrm{C}\right.$ ) (Matthäus \& Haase, 2014). The results for fried potatoes are presented in Table 1. Slight variations were verified with the three oils during frying time, ranging from 62 to $125 \mu \mathrm{g} / 100 \mathrm{~g}$. These results are near to indicative acrylamide values for ready-to-eat French fries $(60 \mu \mathrm{g} / 100 \mathrm{~g})$, and potato crisps $(100 \mu \mathrm{g} /$ $100 \mathrm{~g}$ ) (Matthäus \& Haase, 2014). Fried potatoes at $8 \mathrm{~h}$ had similar acrylamide content between oils ( $\mathrm{p}>0.05$ ), and correspond to the lowest values. The highest acrylamide levels were observed with fried potatoes at $16 \mathrm{~h}$ in PO ( $\mathrm{p}<0.05)$, closely followed by CO at $16 \mathrm{~h}$ and $28 \mathrm{~h}$ or EVOO at $24 \mathrm{~h}$. Globally, a high variability was observed in acrylamide amounts, without an association with oil type, but with an apparent increase with frying hours, particularly for EVOO and CO. Literature data are not consistent on these issues, with most authors reporting no association with oil type (Matthäus \& Haase, 2014), although Zhang et al. (2015), on a 600 frying cycles study with six different oils addressed the possible influence of oil heat transfer coefficients in acrylamide content. Regarding the influence of oil quality, again no consistent associations are found in the literature for simulated or potatoes frying, but with an highlight that the food type may have some influence (Matthäus \& Haase, 2014), On all reports, variability between replicates is usually high, which might hamper statistical significances.

\subsection{Impact of prolonged frying in monounsaturated-rich oils on volatile compounds of fresh white potatoes}

The development of desirable and undesirable flavors in fried potatoes is a combined effect of oil alteration, breakdown products of potatoes constituents, and compounds produced by potato/oil interactions (van Loon, Linssen, Legger, Posthumus, \& Voragen, 2005).

Volatiles emitted from raw potatoes have origin in lipid degradation, due to its lypoxygenase content (van Loon et al., 2005), while those from fried potatoes have various origins, including lipid degradation, sugar/Maillard reactions, sulfur and terpenes degradations (Comandini, Cerretani, Blanda, Bendini, \& Toschi, 2011; van Loon et al., 2005).
Regarding the volatile chemical families analyzed (Table 2), grouped as non-aldehyde and aldehydes, raw potatoes had the lowest total volatile content, wherein aldehydes (alkanals and alkenals) were predominant. During deep-frying, total volatile contents increased in all fried potatoes, reflected in positive Pearson correlations with frying time (EVOO: $\mathrm{r}=0.605, p<0.01$; PO: $\mathrm{r}=0.596, p<0.01$; CO: $\mathrm{r}=0.854, p<0.001)$. However, some oscillations were verified in the individual families and groups, derived probably from partial losses by evaporation during sampling (Matthäus, 2006), as well as from the inherent characteristics of the SPME methodology. This method evaluates the volatiles released and equilibrated in the headspace with the fiber and not its true total content, only achieved by purge-and trap methodologies, being therefore more useful for comparison, as pursued in the present work. The maximum content of total volatiles was observed at $24 \mathrm{~h}$ for potatoes fried in EVOO, resulting mostly from oleic acid oxidation (alkanes and alkanals) and sugar/Maillard reaction degradation products (pyrazines), corresponding to the sample with highest acrylamide content. At $28 \mathrm{~h}$ of frying, no differences were found between samples for total volatiles $(p>0.05)$.

Pyrazines were the main non-aldehyde group, with strong Pearson correlations with frying time on the three oils, but without differences between them. These compounds result mostly from sugar/Maillard reactions degradation from the potatoes (Romano et al., 2012), potentially accumulating in the oils with frying time.

For aldehydes, different patterns were observed along frying time, with higher alkanals formation in EVOO, similar alkenals on the three oils, and higher alkadienals in PO and CO. This is consistent with the fatty acid profile of the oils (Table 1), with higher saturated fatty acids in EVOO, similar monounsaturated on the three oils, and higher linolenic acid in PO and CO.

In terms of volatiles typical of fried potatoes flavor, $E, E-2,4-\mathrm{dec}-$ adienal, derived from peroxidation of linoleic acid (Boskou et al., 2006), was predominant in CO and PO (Fig. 2), while 2,5-dimethylpyrazine (data not shown), formed by Maillard reactions, was the main typical flavor in EVOO fried potatoes. A huge variation with time was found in E,E-2,4-decadienal amounts, ranging from 80 to $1100 \mu \mathrm{g} /$ $100 \mathrm{~g}$ of potatoes, within the literature ranges (Boskou et al., 2006). The minimum value was observed for fried potatoes in EVOO, while the maximum values were observed for fried potatoes in $\mathrm{CO}$ and PO, particularly this last, in agreement with its higher linoleic acid content. E,E-2,4-decadienal amounts should be regarded with caution due to its potential toxicity (Boskou et al., 2006).

In terms of undesirable flavors, nonanal was the most representative in EVOO, while 2-undecenal was more noticeable in potatoes fried in PO and CO (data not shown). These volatile compounds have been described as resulting from oxidation of different oleic acid hydroperoxides (Perkins, 2007), the main fatty acid of fried potatoes. Interestingly, hexanal (data not shown), associated to linoleic acid oxidation and to the loss of "positive" odor attributes in fried potatoes (Comandini et al., 2011), was detected in higher amounts in the raw potatoes, probably favoured by the increased equilibrium in the headspace derived from the lower total amount of volatiles. It decreased up to the $20 \mathrm{~h}$, increasing again thereafter in EVOO and PO. These variations were already described by Alizadeh, Nayebzadeh, \& Mohammadi, 2015 under different frying conditions.

For EVOO fried potatoes, strong positive Pearson correlation was found between total of volatile compounds formed by sugar/Maillard reaction degradation and acrylamide $(\mathrm{r}=0.834, p<0.01)$ at $24 \mathrm{~h}$, particularly with pyrazines $(r=0.797, p<0.01)$, supporting a probable association of the maximum emission of volatiles with the highest acrylamide content.

\subsection{Impact of prolonged frying in monounsaturated-rich oils on color and sensory analysis of fresh white potatoes}

Several studies report the importance of oil absorption during frying 
Table 2

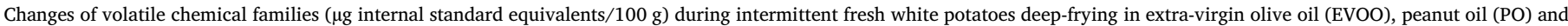
canola oil $(\mathrm{CO})(\mathrm{n}=3)$.

\begin{tabular}{|c|c|c|c|c|c|c|c|c|c|c|}
\hline & & \multirow{2}{*}{$\frac{\text { Oils }}{\text { Fresh }}$} & \multirow{2}{*}{$\begin{array}{l}\text { Potatoes } \\
\text { Raw }\end{array}$} & \multicolumn{6}{|l|}{ Fried at } & \multirow[t]{2}{*}{$\mathrm{r}$} \\
\hline & & & & $8 \mathrm{~h}$ & $12 \mathrm{~h}$ & $16 \mathrm{~h}$ & $20 \mathrm{~h}$ & $24 \mathrm{~h}$ & $28 \mathrm{~h}$ & \\
\hline Alkylbenzenes & $\begin{array}{l}\text { EVOO } \\
\text { PO } \\
\text { CO }\end{array}$ & $\begin{array}{l}1789 \pm 311 \\
2297 \pm 464 \\
1376 \pm 322\end{array}$ & $36 \pm 4$ & $\begin{array}{l}81 \pm 6^{\mathrm{a}, \mathrm{A}} \\
174 \pm 36^{\mathrm{b}, \mathrm{A}} \\
194 \pm 18^{\mathrm{b}, \mathrm{AB}}\end{array}$ & $\begin{array}{l}66 \pm 3^{\mathrm{a}, \mathrm{A}} \\
185 \pm 4^{\mathrm{b}, \mathrm{AB}} \\
178 \pm 3^{\mathrm{b}, \mathrm{B}}\end{array}$ & $\begin{array}{l}319 \pm 9^{\mathrm{b}, \mathrm{D}} \\
202 \pm 11^{\mathrm{a}, \mathrm{ABC}} \\
212 \pm 30^{\mathrm{a}, \mathrm{AB}}\end{array}$ & $\begin{array}{l}114 \pm 16^{\mathrm{a}, \mathrm{B}} \\
177 \pm 4^{\mathrm{b}, \mathrm{AB}} \\
198 \pm 21^{\mathrm{b}, \mathrm{AB}}\end{array}$ & $\begin{array}{l}185 \pm 6^{\mathrm{a}, \mathrm{C}} \\
220 \pm 13^{\mathrm{b}, \mathrm{BC}} \\
250 \pm 17^{\mathrm{b}, \mathrm{B}}\end{array}$ & $\begin{array}{l}165 \pm 18^{\mathrm{a}, \mathrm{C}} \\
243 \pm 6^{\mathrm{b}, \mathrm{C}} \\
324 \pm 36^{\mathrm{c}, \mathrm{C}}\end{array}$ & $\begin{array}{l}0.327^{\mathrm{NS}} \\
0.735^{\text {*** }} \\
0.788^{\text {*** }}\end{array}$ \\
\hline Carboxylic Acids & $\begin{array}{l}\text { EVOO } \\
\text { PO } \\
\text { CO }\end{array}$ & $\begin{array}{l}\text { n.d. } \\
80 \pm 24 \\
\text { n.d. }\end{array}$ & n.d. & $\begin{array}{l}12 \pm 1^{\mathrm{a}, \mathrm{A}} \\
124 \pm 23^{\mathrm{b}, \mathrm{C}} \\
\text { n.d. }\end{array}$ & $\begin{array}{l}18 \pm 5^{\mathrm{a}, \mathrm{A}} \\
89 \pm 1^{\mathrm{b}, \mathrm{B}} \\
\text { n.d. }\end{array}$ & $\begin{array}{l}23 \pm 2^{\mathrm{a}, \mathrm{A}} \\
90 \pm 1^{\mathrm{b}, \mathrm{B}} \\
\text { n.d. }\end{array}$ & $\begin{array}{l}26 \pm 5^{\mathrm{a}, \mathrm{A}} \\
53 \pm 0^{\mathrm{b}, \mathrm{A}} \\
\text { n.d. }\end{array}$ & $\begin{array}{l}434 \pm 52^{\mathrm{C}} \\
\text { n.d. } \\
\text { n.d. }\end{array}$ & $\begin{array}{l}204 \pm 41^{\mathrm{b}, \mathrm{B}} \\
\text { n.d. } \\
62 \pm 2^{\mathrm{a}}\end{array}$ & $\begin{array}{l}0.684^{* * *} \\
-0.952^{* * * *} \\
0.654^{* *}\end{array}$ \\
\hline $\begin{array}{l}\text { Furan } \\
\quad \text { derivatives }\end{array}$ & $\begin{array}{l}\text { EVOO } \\
\text { PO } \\
\text { CO }\end{array}$ & $\begin{array}{l}\text { n.d. } \\
\text { n.d. } \\
\text { n.d. }\end{array}$ & $17 \pm 0$ & $\begin{array}{l}9 \pm 0^{\mathrm{a}, \mathrm{A}} \\
26 \pm 0^{\mathrm{c}, \mathrm{A}} \\
20 \pm 3^{\mathrm{b}, \mathrm{A}}\end{array}$ & $\begin{array}{l}19 \pm 0^{\mathrm{a}, \mathrm{C}} \\
28 \pm 0^{\mathrm{c}, \mathrm{A}} \\
25 \pm 1^{\mathrm{b}, \mathrm{AB}}\end{array}$ & $\begin{array}{l}56 \pm 1^{\mathrm{b}, \mathrm{D}} \\
27 \pm 4^{\mathrm{a}, \mathrm{A}} \\
23 \pm 2^{\mathrm{a}, \mathrm{AB}}\end{array}$ & $\begin{array}{l}18 \pm 00^{\mathrm{a}, \mathrm{C}} \\
63 \pm 2^{\mathrm{c}, \mathrm{C}} \\
26 \pm 0^{\mathrm{b}, \mathrm{B}}\end{array}$ & $\begin{array}{l}21 \pm 0^{\mathrm{a}, \mathrm{C}} \\
35 \pm 4^{\mathrm{b}, \mathrm{B}} \\
25 \pm 3^{\mathrm{a}, \mathrm{AB}}\end{array}$ & $\begin{array}{l}15 \pm 2^{\mathrm{a}, \mathrm{B}} \\
35 \pm 2^{\mathrm{b}, \mathrm{B}} \\
33 \pm 3^{\mathrm{b}, \mathrm{C}}\end{array}$ & $\begin{array}{l}-0.005^{\mathrm{NS}} \\
0.364^{\mathrm{NS}} \\
0.788^{\text {**** }}\end{array}$ \\
\hline Pyrazine & $\begin{array}{l}\text { EVOO } \\
\text { PO } \\
\text { CO }\end{array}$ & $\begin{array}{l}\text { n.d. } \\
\text { n.d. } \\
\text { n.d. }\end{array}$ & n.d. & $\begin{array}{l}488 \pm 16^{\mathrm{a}, \mathrm{A}} \\
838 \pm 28^{\mathrm{b}, \mathrm{A}} \\
776 \pm 51^{\mathrm{b}, \mathrm{A}}\end{array}$ & $\begin{array}{l}506 \pm 21^{\mathrm{a}, \mathrm{A}} \\
977 \pm 5^{\mathrm{b}, \mathrm{B}} \\
954 \pm 25^{\mathrm{b}, \mathrm{A}}\end{array}$ & $\begin{array}{l}1160 \pm 34^{\mathrm{b}, \mathrm{B}} \\
953 \pm 86^{\mathrm{a}, \mathrm{AB}} \\
904 \pm 46^{\mathrm{a}}\end{array}$ & $\begin{array}{l}1069 \pm 223^{\mathrm{B}} \\
1035 \pm 7^{\mathrm{B}} \\
984 \pm 42^{\mathrm{A}}\end{array}$ & $\begin{array}{l}1707 \pm 78^{\mathrm{c}, \mathrm{C}} \\
1279 \pm 51^{\mathrm{a}, \mathrm{C}} \\
1511 \pm 30^{\mathrm{b}, \mathrm{B}}\end{array}$ & $\begin{array}{l}1529 \pm 13^{\mathrm{ab}, \mathrm{C}} \\
1329 \pm 15^{\mathrm{a}, \mathrm{C}} \\
1746 \pm 181^{\mathrm{b}, \mathrm{C}}\end{array}$ & $\begin{array}{l}0.907^{k * k} \\
0.930^{k * k} \\
0.894^{k * k}\end{array}$ \\
\hline Pyrrole & $\begin{array}{l}\text { EVOO } \\
\text { PO } \\
\text { CO }\end{array}$ & $\begin{array}{l}\text { n.d. } \\
\text { n.d. } \\
\text { n.d. }\end{array}$ & n.d. & $\begin{array}{l}\text { n.d. } \\
\text { n.d. } \\
\text { n.d. }\end{array}$ & $\begin{array}{l}\text { n.d. } \\
\text { n.d. } \\
22 \pm 1^{\mathrm{A}}\end{array}$ & $\begin{array}{l}\text { n.d. } \\
32 \pm 4^{\mathrm{B}} \\
28 \pm 0^{\mathrm{A}}\end{array}$ & $\begin{array}{l}\text { n.d. } \\
24 \pm 0^{\mathrm{b}, \mathrm{A}} \\
20 \pm 1^{\mathrm{a}, \mathrm{A}}\end{array}$ & $\begin{array}{l}32 \pm 2 \\
30 \pm 0^{\mathrm{B}} \\
37 \pm 4^{\mathrm{A}}\end{array}$ & $\begin{array}{l}27 \pm 6^{\mathrm{a}} \\
45 \pm 3^{\mathrm{ab}, \mathrm{C}} \\
56 \pm 16^{\mathrm{b}, \mathrm{B}}\end{array}$ & $\begin{array}{l}0.796^{\text {***k}} \\
0.898^{\text {*k* }} \\
0.860^{\text {k*k* }}\end{array}$ \\
\hline $\begin{array}{l}\text { TOTAL Non- } \\
\text { Aldehydes }\end{array}$ & $\begin{array}{l}\text { EVOO } \\
\text { PO } \\
\text { CO }\end{array}$ & $\begin{array}{l}3290 \pm 349 \\
3753 \pm 483 \\
1974 \pm 442\end{array}$ & $83 \pm 7$ & $\begin{array}{l}635 \pm 17^{\mathrm{a}, \mathrm{A}} \\
1039 \pm 7^{\mathrm{b}, \mathrm{A}} \\
990 \pm 58^{\mathrm{b}, \mathrm{A}}\end{array}$ & $\begin{array}{l}642 \pm 21^{\mathrm{a}, \mathrm{A}} \\
1190 \pm 7^{\mathrm{b}, \mathrm{B}} \\
1179 \pm 24^{\mathrm{b}, \mathrm{A}}\end{array}$ & $\begin{array}{l}1597 \pm 31^{\mathrm{b}, \mathrm{BC}} \\
1214 \pm 85^{\mathrm{a}, \mathrm{B}} \\
1168 \pm 63^{\mathrm{a}, \mathrm{A}}\end{array}$ & $\begin{array}{l}1292 \pm 198^{\mathrm{B}} \\
1299 \pm 8^{\mathrm{B}} \\
1228 \pm 53^{\mathrm{A}}\end{array}$ & $\begin{array}{l}2079 \pm 95^{\mathrm{c}, \mathrm{D}} \\
1563 \pm 55^{\mathrm{a}, \mathrm{C}} \\
1823 \pm 12^{\mathrm{b}, \mathrm{B}}\end{array}$ & $\begin{array}{l}1756 \pm 13^{\mathrm{a}, \mathrm{C}} \\
1783 \pm 22^{\mathrm{a}, \mathrm{D}} \\
2208 \pm 197^{\mathrm{b}, \mathrm{C}}\end{array}$ & $\begin{array}{l}0.851^{\text {k*k }} \\
0.946^{\text {*k* }} \\
0.891^{\text {*k*k}}\end{array}$ \\
\hline Alkanals & $\begin{array}{l}\text { EVOO } \\
\text { PO } \\
\text { CO }\end{array}$ & $\begin{array}{l}105 \pm 79 \\
85 \pm 6 \\
\text { n.d. }\end{array}$ & $337 \pm 160$ & $\begin{array}{l}580 \pm 5^{\mathrm{b}, \mathrm{A}} \\
592 \pm 30^{\mathrm{b}, \mathrm{CD}} \\
437 \pm 23^{\mathrm{a}, \mathrm{AB}}\end{array}$ & $\begin{array}{l}645 \pm 14^{\mathrm{b}, \mathrm{A}} \\
625 \pm 16^{\mathrm{b}, \mathrm{D}} \\
380 \pm 1^{\mathrm{a}, \mathrm{A}}\end{array}$ & $\begin{array}{l}1725 \pm 30^{\mathrm{b}, \mathrm{D}} \\
511 \pm 20^{\mathrm{a}, \mathrm{B}} \\
474 \pm 21^{\mathrm{a}, \mathrm{B}}\end{array}$ & $\begin{array}{l}819 \pm 67^{\mathrm{b}, \mathrm{B}} \\
431 \pm 1^{\mathrm{a}, \mathrm{A}} \\
466 \pm 41^{\mathrm{a}, \mathrm{B}}\end{array}$ & $\begin{array}{l}1193 \pm 37^{\mathrm{c}, \mathrm{C}} \\
558 \pm 6^{\mathrm{b}, \mathrm{B}} \\
428 \pm 2^{\mathrm{a}, \mathrm{AB}}\end{array}$ & $\begin{array}{l}910 \pm 27^{\mathrm{c}, \mathrm{B}} \\
536 \pm 9^{\mathrm{a}, \mathrm{B}} \\
629 \pm 23^{\mathrm{b}, \mathrm{C}}\end{array}$ & $\begin{array}{l}0.299^{\mathrm{NS}} \\
-0.434^{\mathrm{NS}} \\
0.671^{\text {** }}\end{array}$ \\
\hline Alkenals & $\begin{array}{l}\text { EVOO } \\
\text { PO } \\
\text { CO }\end{array}$ & $\begin{array}{l}843 \pm 19 \\
\text { n.d. } \\
\text { n.d. }\end{array}$ & $117 \pm 60$ & $\begin{array}{l}301 \pm 10^{\mathrm{a}, \mathrm{A}} \\
556 \pm 81^{\mathrm{b}, \mathrm{A}} \\
435 \pm 33^{\mathrm{b}, \mathrm{A}}\end{array}$ & $\begin{array}{l}31 \pm 2^{\mathrm{a}, \mathrm{A}} \\
764 \pm 17^{\mathrm{c}, \mathrm{C}} \\
470 \pm 23^{\mathrm{b}, \mathrm{A}}\end{array}$ & $\begin{array}{l}1608 \pm 48^{\mathrm{c}, \mathrm{D}} \\
756 \pm 37^{\mathrm{b}, \mathrm{C}} \\
575 \pm 76^{\mathrm{a}, \mathrm{AB}}\end{array}$ & $\begin{array}{l}503 \pm 39^{\mathrm{a}, \mathrm{B}} \\
612 \pm 14^{\mathrm{b}, \mathrm{AB}} \\
562 \pm 52^{\mathrm{ab}, \mathrm{AB}}\end{array}$ & $\begin{array}{l}693 \pm 94^{\mathrm{b}, \mathrm{C}} \\
689 \pm 37^{\mathrm{b}, \mathrm{BC}} \\
519 \pm 24^{\mathrm{a}, \mathrm{AB}}\end{array}$ & $\begin{array}{l}751 \pm 98^{\mathrm{C}} \\
679 \pm 28^{\mathrm{BC}} \\
655 \pm 86^{\mathrm{B}}\end{array}$ & $\begin{array}{l}0.250^{\mathrm{NS}} \\
0.147^{\mathrm{NS}} \\
0.710^{\text {*** }}\end{array}$ \\
\hline Alkadienals & $\begin{array}{l}\text { EVOO } \\
\text { PO } \\
\text { CO }\end{array}$ & $\begin{array}{l}480 \pm 50 \\
\text { n.d. } \\
\text { n.d. }\end{array}$ & $18 \pm 10$ & $\begin{array}{l}128 \pm 6^{\mathrm{a}, \mathrm{AB}} \\
240 \pm 31^{\mathrm{b}, \mathrm{A}} \\
854 \pm 68^{\mathrm{c}, \mathrm{AB}}\end{array}$ & $\begin{array}{l}110 \pm 0^{\mathrm{a}, \mathrm{A}} \\
1313 \pm 44^{\mathrm{c}, \mathrm{D}} \\
661 \pm 25^{\mathrm{b}, \mathrm{A}}\end{array}$ & $\begin{array}{l}524 \pm 24^{\mathrm{a}, \mathrm{E}} \\
1122 \pm 72^{\mathrm{c}, \mathrm{C}} \\
740 \pm 76^{\mathrm{b}, \mathrm{AB}}\end{array}$ & $\begin{array}{l}188 \pm 21^{\mathrm{a}, \mathrm{BC}} \\
926 \pm 29^{\mathrm{c}, \mathrm{B}} \\
727 \pm 88^{\mathrm{b}, \mathrm{AB}}\end{array}$ & $\begin{array}{l}245 \pm 32^{\mathrm{a}, \mathrm{CD}} \\
1018 \pm 63^{\mathrm{c}, \mathrm{C}} \\
692 \pm 34^{\mathrm{b}, \mathrm{AB}}\end{array}$ & $\begin{array}{l}268 \pm 34^{\mathrm{a}, \mathrm{D}} \\
972 \pm 39^{\mathrm{b}, \mathrm{B}} \\
865 \pm 100^{\mathrm{b}, \mathrm{B}}\end{array}$ & $\begin{array}{l}0.270^{\mathrm{NS}} \\
0.374^{\mathrm{NS}} \\
0.069^{\mathrm{NS}}\end{array}$ \\
\hline $\begin{array}{l}\text { TOTAL } \\
\text { Aldehydes }\end{array}$ & $\begin{array}{l}\text { EVOO } \\
\text { PO } \\
\text { CO }\end{array}$ & $\begin{array}{l}1427 \pm 97 \\
85 \pm 6 \\
\text { n.d. }\end{array}$ & $472 \pm 231$ & $\begin{array}{l}1009 \pm 17^{\mathrm{a}, \mathrm{A}} \\
1388 \pm 66^{\mathrm{b}, \mathrm{A}} \\
1725 \pm 102^{\mathrm{c}, \mathrm{A}}\end{array}$ & $\begin{array}{l}1070 \pm 13^{\mathrm{a}, \mathrm{A}} \\
2702 \pm 37^{\mathrm{c}, \mathrm{D}} \\
1511 \pm 41^{\mathrm{b}, \mathrm{A}}\end{array}$ & $\begin{array}{l}3857 \pm 83^{\mathrm{c}, \mathrm{D}} \\
2389 \pm 105^{\mathrm{b}, \mathrm{C}} \\
1788 \pm 141^{\mathrm{a}, \mathrm{AB}}\end{array}$ & $\begin{array}{l}1510 \pm 104^{\mathrm{a}, \mathrm{B}} \\
1969 \pm 35^{\mathrm{b}, \mathrm{B}} \\
1756 \pm 148^{\mathrm{ab}, \mathrm{AB}}\end{array}$ & $\begin{array}{l}2131 \pm 73^{\mathrm{b}, \mathrm{C}} \\
2265 \pm 87^{\mathrm{b}, \mathrm{C}} \\
1639 \pm 48^{\mathrm{a}, \mathrm{A}}\end{array}$ & $\begin{array}{l}1929 \pm 130^{\mathrm{C}} \\
2187 \pm 62^{\mathrm{BC}} \\
2149 \pm 170^{\mathrm{B}}\end{array}$ & $\begin{array}{l}0.276^{\mathrm{NS}} \\
0.268^{\mathrm{NS}} \\
0.526^{\text {* }}\end{array}$ \\
\hline TOTAL Volatiles & $\begin{array}{l}\text { EVOO } \\
\text { PO } \\
\text { CO }\end{array}$ & $\begin{array}{l}4717 \pm 413 \\
3838 \pm 489 \\
1974 \pm 442\end{array}$ & $554 \pm 234$ & $\begin{array}{l}1669 \pm 43^{\mathrm{a}, \mathrm{A}} \\
2551 \pm 66^{\mathrm{b}, \mathrm{A}} \\
2716 \pm 196^{\mathrm{b}, \mathrm{A}}\end{array}$ & $\begin{array}{l}1734 \pm 46^{\mathrm{a}, \mathrm{A}} \\
3981 \pm 52^{\mathrm{c}, \mathrm{C}} \\
2690 \pm 80^{\mathrm{b}, \mathrm{A}}\end{array}$ & $\begin{array}{l}5477 \pm 62^{\mathrm{c}, \mathrm{D}} \\
3694 \pm 234^{\mathrm{b}, \mathrm{C}} \\
2956 \pm 251^{\mathrm{a}, \mathrm{A}}\end{array}$ & $\begin{array}{l}2858 \pm 369^{\mathrm{B}} \\
3321 \pm 32^{\mathrm{B}} \\
2983 \pm 246^{\mathrm{A}}\end{array}$ & $\begin{array}{l}6297 \pm 806^{\mathrm{b}, \mathrm{D}} \\
3828 \pm 174^{\mathrm{a}, \mathrm{C}} \\
3714 \pm 66^{\mathrm{a}, \mathrm{B}}\end{array}$ & $\begin{array}{l}3889 \pm 216^{\mathrm{C}} \\
3970 \pm 102^{\mathrm{C}} \\
4464 \pm 426^{\mathrm{C}}\end{array}$ & $\begin{array}{l}0.605^{\text {kk }} \\
0.596^{\text {kk }} \\
0.864^{\text {kk* }}\end{array}$ \\
\hline
\end{tabular}

${ }^{\mathrm{a}-\mathrm{c}}$ Statistically significant differences between vegetable oils or ${ }^{\mathrm{A}-\mathrm{D}}$ between frying time $(p<0.05)$.

$\mathrm{r}$ - Pearson correlation with frying time: significant at the $0.05,{ }^{* * *} 0.01$, and ${ }^{* * *} 0.001$ level (2-tailed), ${ }^{\text {NS }}$ - not significant.

and its implication on the sensory quality of fried foods and acceptability (Decker \& Ferruzzi, 2013; Matthäus, 2006). In this sense, we have carried out sensory analysis of fried potatoes in the different vegetable oils, over frying time. Instrumental measure of color was also included to corroborate the sensory findings regarding this attribute. Indeed, color development in fried potatoes is strictly related to consumer perception of quality (Pedreschi, 2012) and several variables may affect it, including oil type, temperature, frying time, and sample

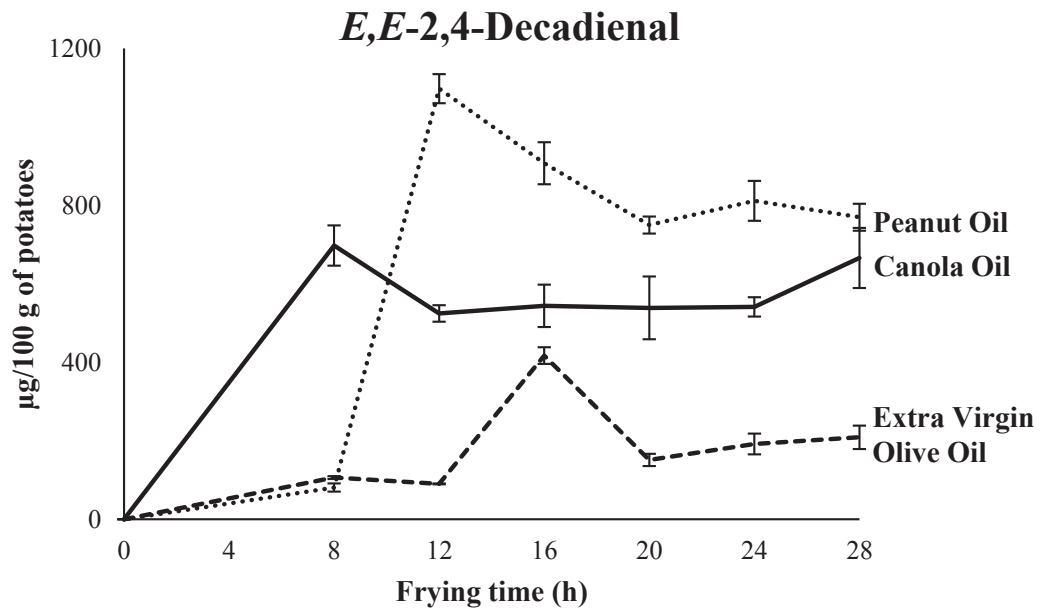

Fig. 2. Changes of $E, E-2,4$-decadienal during intermittent fresh white potatoes deep-frying for Extra Virgin Olive Oil (--.-), Peanut Oil (…...), and Canola Oil $(\longrightarrow)(\mathrm{n}=3)$. 
dimensions (Krokida, Oreopoulou, Maroulis, \& Marinos-Kouris, 2001).

According to the literature, the ideal tonality for fried potatoes is between -5 and 0 for coordinate $\mathrm{a}^{*}$, and higher than 10 for coordinate $\mathrm{b}^{*}$ (Krokida et al., 2001), while higher $\mathrm{L}^{*}$ value indicates lighter color, desirable in fried potatoes (Garayo \& Moreira, 2002). Although frying time was identical for per batch ( $6 \mathrm{~min}$ ), instrumental color determinations made on the surface reflected some variability. Regardless of the oil type or frying time, coordinate $a^{*}$ was generally higher $\left(4<\mathrm{a}^{*}<10\right)$, while coordinate $\mathrm{b}^{*}$ was in accordance, and $\mathrm{L}^{*}$ was always superior to 45 . On average, and in comparison with raw peeled potatoes $\left[\mathrm{L}^{*}(72), \mathrm{a}^{*}(-1), \mathrm{b}^{*}(30)\right]$, deep-frying promoted a decrease of coordinate $\mathrm{L}^{*}(-16)$ and an increase of coordinates $\mathrm{a}^{*}(+8)$ and $\mathrm{b}^{*}$ $(+4)$, intensifying the red tones, as expected (Pedreschi, 2012). With increased frying time, coordinate $\mathrm{b}^{*}$ (yellow) was kept similar between samples $(p>0.05)$ while coordinate $\mathrm{a}^{*}$ presented an irregular pattern. Still, at $28 \mathrm{~h}$, potatoes fried in PO presented the higher color changes [ $\left.\Delta \mathrm{E}(28), \mathrm{L}^{*}(52), \mathrm{a}^{*}(10), \mathrm{b}^{*}(37)\right]$, while fried potatoes in CO presented the lowest $\left[\Delta E(18), L^{*}(62), a^{*}(6), b^{*}(37)\right]$. Therefore, weak correlations with frying time were only observed with PO for $\mathrm{L}^{*}(\mathrm{r}=-0.539$, $p<0.05)$ and $\Delta \mathrm{E}(\mathrm{r}=-0.485, p<0.05)$. Regarding the browning index, all samples were within the 44-49 range, without association with frying time or oil type.

For the sensory analysis, Fig. 3 resumes the information on the three oils for the same day $(\mathrm{A}-\mathrm{C})$, together with the variations for the same oil over the three days (D-E). As previously explained, potatoes fried in the oils heated for $28 \mathrm{~h}$ were not given to the panel as these had more than $25 \%$ of TPC.

Despite the recognized differences in the oils natural taste, with EVOO presenting a bitter, astringent and pungent flavor due to its rich phenols composition (Servili et al., 2004) while refined oils have more neutral taste (Matthäus, 2006), the sensory panel did not detected marked differences between samples in the first day $(p>0.05)$ (Fig. 3A). However, increased frying time, and consequently oil degradation, promoted perceptible changes on sensory attributes of fried potatoes. In the second day (Fig. 3B), the sensory panel detected statistically significant differences $(p<0.05)$ associated to color intensity (CO > PO, EVOO), color homogeneity (EVOO, CO > PO), odor quality (EVOO, $\mathrm{CO}>\mathrm{PO}$ ), crispiness (CO > PO, EVOO), and firmness (CO > EVOO, PO). However, in the last day (Fig. 3C), differences between samples were only associated to taste quality (PO > EVOO, $\mathrm{CO})$.

When each oil was analyzed separately, panellists were able to detect degradation in EVOO (Fig. 3D) with significant decrease $(p<0.05)$ for taste quality over time (day 1 , day $2>$ day 3 ), as well as in $\mathrm{CO}$ (Fig. 3E), while no significant negative evolution was perceived in PO (Fig. 3E). Aftertaste increase contributed clearly for taste quality reduction in EVOO and $\mathrm{CO}$, together with a reduction on odor intensity and quality, again not perceived in PO. Only color intensity was consistent on the three oils, with a perceived increased over time, despite being significant only for CO (Fig. 3F) (day 3, day $2>$ day 1 ), in agreement with the instrumental color readings. This evolution was corroborated with weak Pearson correlations, negative for taste quality in EVOO $(\mathrm{r}=-0.399, p<0.05)$, positive for crispiness in $\mathrm{PO}$ $(\mathrm{r}=0.428, p<0.01)$, and again positive for color intensity in CO ( $\mathrm{r}=0.492, p<0.01)$. Regarding acceptability, statistically significant differences were not found in each day or oil type, but a weak negative Pearson correlation between frying time and acceptability was verified for EVOO $(r=-0.349, p<0.05)$.

In addition, Pearson and Spearman correlations were performed to understand what sensory attributes affected fried potatoes acceptability on each day to ascertain the vegetable oil type influences. Only moderate to strong positive Pearson correlations were found. In the first and second days acceptability was associated to taste quality, for EVOO $(\mathrm{r}=0.817, p<0.001$ and $\mathrm{r}=0.674, p<0.05)$, PO $(\mathrm{r}=0.791$, $p<0.01$ and $\mathrm{r}=0.939, p<0.001)$, and CO ( $\mathrm{r}=0.675, p<0.05$ and $\mathrm{r}=0.927, p<0.001)$. In the third day, EVOO was associated to odor and taste qualities $(\mathrm{r}=0.769, p<0.01$, and $\mathrm{r}=0.905$, $p<0.001$, respectively); PO was associated to odor quality and firmness ( $\mathrm{r}=0.763, p<0.01$, and $\mathrm{r}=0.837, p<0.001$, respectively); and in CO associated to taste quality ( $\mathrm{r}=0.843, p<0.001)$. Although acceptability is also linked to perception of color, namely golden-yellow color acquired during deep-frying, in this work no correlations were found. However, the relationship between sensorial (subjective) and instrumental analysis (objective) was studied by Pearson correlations. In general, weak correlations between color intensity and $\mathrm{L}^{*}$ coordinate $(\mathrm{r}=-0.479, p<0.05)$, and between color homogeneity and $\mathrm{a}^{*}$ coordinate $(\mathrm{r}=0.416, \mathrm{p}<0.05)$ were found on the first day, increasing its significance on the third day $(r=-0.764$
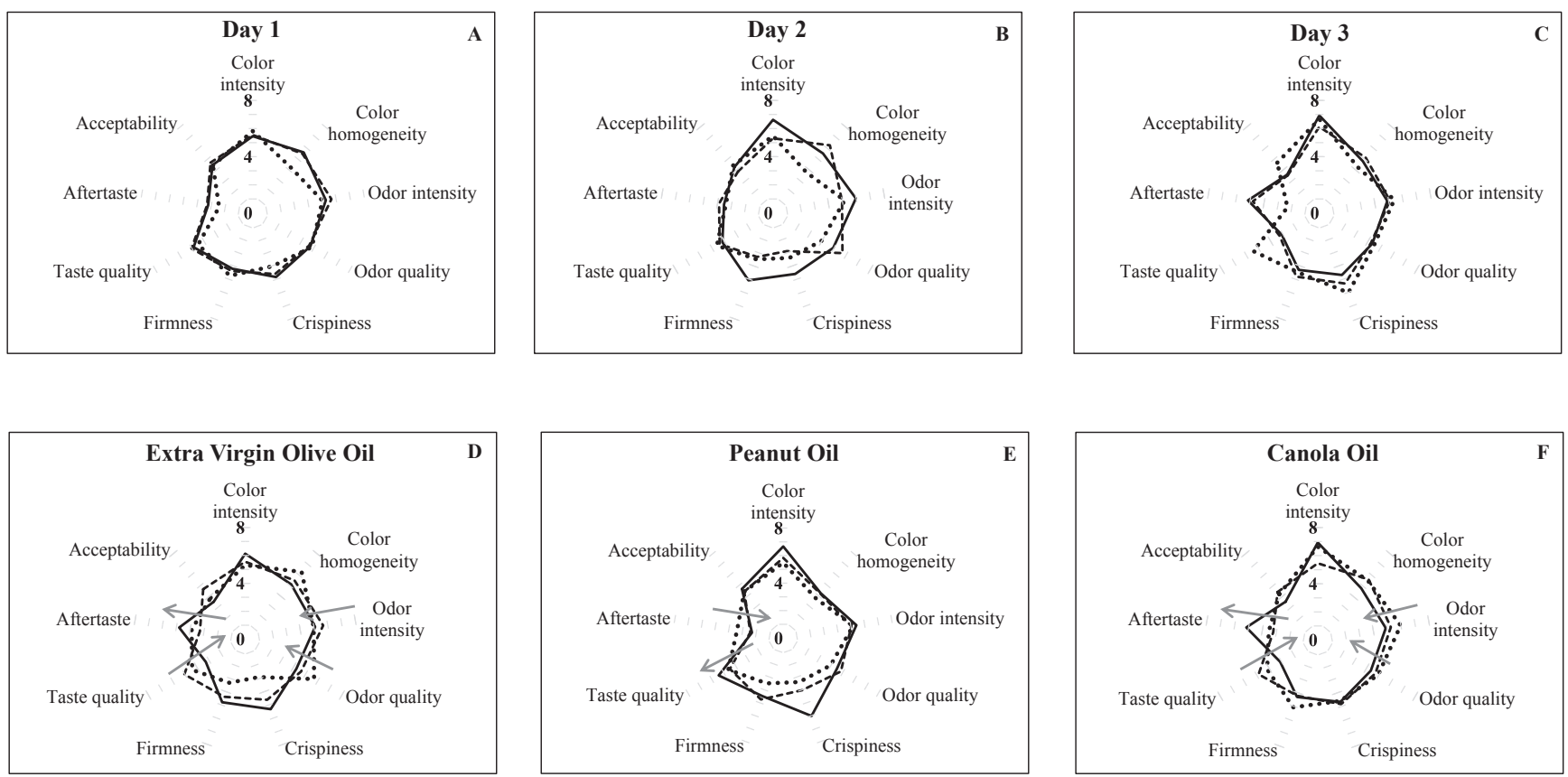

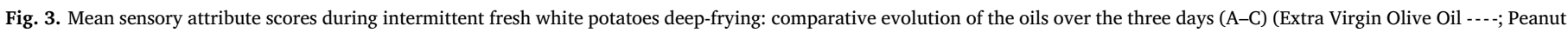

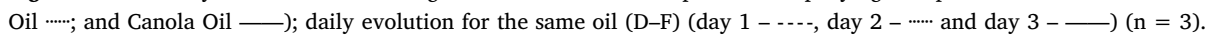


Table 3

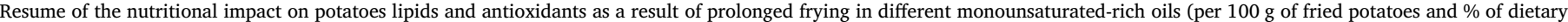
recommendations for adults).

\begin{tabular}{|c|c|c|c|c|c|c|c|}
\hline \multirow[t]{2}{*}{ Fried potatoes } & \multicolumn{2}{|c|}{ Extra-virgin olive oil } & \multicolumn{2}{|l|}{ Peanut oil } & \multicolumn{2}{|l|}{ Canola oil } & \multirow[t]{2}{*}{ Reference dietary recommendations per day } \\
\hline & $8 \mathrm{~h}$ & $28 \mathrm{~h}$ & $8 \mathrm{~h}$ & $28 \mathrm{~h}$ & $8 \mathrm{~h}$ & $28 \mathrm{~h}$ & \\
\hline Lipids (g), of which & 9.0 & 9.3 & 9.4 & 9.4 & 11.2 & 11.1 & $70 \mathrm{~g}^{*}$ \\
\hline SFA $(g)$ & 1.5 & 1.6 & 1.7 & 1.7 & 0.9 & 0.9 & $<20 \mathrm{~g}^{*}$ \\
\hline MUFA (g) & 6.7 & 6.2 & 5.3 & 4.9 & 7.2 & 6.5 & $>20 \mathrm{~g}^{*}$ \\
\hline PUFA $(g)$ & 0.8 & 0.5 & 2.3 & 1.7 & 3.0 & 2.3 & $>20 \mathrm{~g}^{*}$ \\
\hline Trans (g) & 0.01 & 0.03 & 0.03 & 0.04 & 0.04 & 0.06 & $<2 \mathrm{~g}^{\text {* }}$ \\
\hline Vitamin C (mg) & $46(58 \%)$ & $18(23 \%)$ & $45(56 \%)$ & $16(20 \%)$ & $48(60 \%)$ & $19(24 \%)$ & $80 \mathrm{mg}^{*}$ \\
\hline Vitamin E (mg) & $0.4(3 \%)$ & $0.5(4 \%)$ & $0.9(8 \%)$ & $0.8(7 \%)$ & $3.3(28 \%)$ & $1.5(13 \%)$ & $12 \mathrm{mg}^{*}$ \\
\hline Phenolic compounds (mg) & 14 & 17 & 9 & 15 & 10 & 15 & NR \\
\hline Antioxidant activity & + & - & + & - & + & - & NR \\
\hline Acrylamide $^{\$}(\mu \mathrm{g})$ & 77 & 92 & 75 & 96 & 62 & 105 & NR \\
\hline Volatile aldehydes (mg) & 1.0 & 1.9 & 1.4 & 2.2 & 1.7 & 2.2 & NR \\
\hline
\end{tabular}

"Regulation (EU) No. 1169/2011, 2011; NR - no recommendations.

${ }^{\$}$ EFSA estimated the mean dietary acrylamide exposures from 0.4 to $1.9 \mu \mathrm{g} / \mathrm{kg}$ body weight per day (EFSA, 2015).

and 0.749, respectively, $p<0.05$ ) revealing more consistent patterns among assessors.

From the assessor's perspective, other sensorial attributes than color were determinant for acceptability of fried potatoes, such as taste and odor qualities, firmness, and probably taste habits, as $\mathrm{CO}$ is still not common in Portugal.

\section{Conclusions}

The impact of prolonged frying on potatoes nutritional and sensory qualities was studied, including vitamins and antioxidant activity. The results for fried potato composition are compiled in Table 3, using as reference the samples at $8 \mathrm{~h}$ and $28 \mathrm{~h}$ of frying to demonstrate the highest gains and losses with prolonged frying. Globally, these results show that fried potatoes bioactive compounds are heavily affected by the degradation extent of the frying oil.

From a health point of view, it was particularly noticeable that frying in used oil, even if close to the recommended limits for frying, has highly negative effects on fried potatoes composition. Vitamin C was significantly reduced with frying time, from around $60 \%$ of dietary recommendation at $8 \mathrm{~h}$ to only $20 \%$, on a $100 \mathrm{~g}$ dose basis. Additionally, the potential antioxidant activity of the product was heavily affected, being almost absent after $12 \mathrm{~h}$ of frying, half of the average frying time allowed in this assay. Indeed, despite containing several antioxidants compounds, as ascorbic acid itself, vitamin E, and phenolic compounds, these were inefficient in the in vitro tests for antioxidant activity, giving an interesting perception on what can occur in the body once ingested, with the degraded lipids consuming all the potential antioxidant activity of the product. Therefore, they cannot be regarded as being truly available once ingested being interesting to perform bioavailability studies in the future to corroborate it. It also highlights for the permissiveness of the $25 \%$ total polar compounds limit for frying oils.

Regarding the three monounsaturated-rich oils, the differences observed were reduced. From a nutritional point of view, $\mathrm{CO}$ was more equilibrated, with interesting amounts of essential fatty acids and vitamin E, superior during all the frying sessions. However, by being richer in polyunsaturated fatty acids, more prone to oxidation, higher amounts of lipid oxidation were inevitably observed in $\mathrm{CO}$ and PO. Regarding EVOO, its richness in phenolic compounds, one of its main positive health highlights in comparison with other monounsaturated fats, originated fries with higher phenolic compounds, particularly in the first frying hours.

\section{Acknowledgments}

The authors acknowledge the financial support from PRODER (Contract $\mathrm{n}^{\circ}$ 53988), co-financed by FAEDER, and from project UID/ QUI/50006/2013 - POCI/01/0145/FEDER/007265 with financial support from FCT/MEC through national funds, co-financed by FEDER, under the Partnership Agreement PT2020 and the PhD Grant-SFRH/ BD/82285/2011 attributed to Carla S.P. Santos. Lucía Molina García also acknowledges the financial support from Campus de Excelencia Internacional Agroalimentario (ceiA3) and University of Jaén, from Spain.

\section{References}

Alizadeh, L., Nayebzadeh, K., \& Mohammadi, A. (2015). A comparative study on the in vitro antioxidant activity of tocopherol and extracts from rosemary and Ferulago angulata on oil oxidation during deep frying of potato slices. Journal of Food Science and Technology, 53(1), 611-620. http://dx.doi.org/10.1007/s13197-015-2062-2.

Blessington, T., Nzaramba, M. N., Scheuring, D. C., Hale, A. L., Reddivari, L. J., \& Miller, C., Jr. (2010). Cooking methods and storage treatments of potato: Effects on carotenoids, antioxidant activity, and phenolics. American Journal of Potato Research, 87, 479-491. http://dx.doi.org/10.1007/s12230-010-9150-7.

Boskou, G., Salta, F. N., Chiou, A., Troullidou, E., \& Andrikopoulos, N. K. (2006). Content of trans, trans-2,4-decadienal in deep-fried and pan-fried potatoes. European Journal of Lipid Science and Technology, 108(2), 109-115. http://dx.doi.org/10.1002/ejlt. 200500236.

Burmeister, A., Bondiek, S., Apel, L., Kühne, C., Hillebrand, S., \& Fleischmann, P. (2011). Comparison of carotenoid and anthocyanin profiles of raw and boiled Solanum tuberosum and Solanum phureja tubers. Journal of Food Composition and Analysis, 24(6), 865-872.

Camire, M. E., Kubow, S., \& Donnelly, D. J. (2009). Potatoes and human health. Critical Reviews in Food Science and Nutrition, 49, 823-840. http://dx.doi.org/10.1080/ 10408390903041996.

Carlson, B. L., \& Tabacchi, M. H. (1986). Frying oil deterioration and vitamin loss during food service operation. Journal of Food Science, 51, 218-221. http://dx.doi.org/10. 1111/j.1365-2621.1986.tb10874.x.

Casal, S., Malheiro, R., Sendas, A., Oliveira, B. P. P., \& Pereira, J. A. (2010). Olive oil stability under deep-frying conditions. Food and Chemical Toxicology, 48(10), 2972-2979. http://dx.doi.org/10.1016/j.fct.2010.07.036.

Chiou, A., Kalogeropoulos, N., Boskou, G., \& Salta, F. N. (2012). Migration of health promoting microconstituents from frying vegetable oils to French fries. Food Chemistry, 133(4), 1255-1263. http://dx.doi.org/10.2016/j.foodchem.2011.08.068.

Comandini, P., Cerretani, L., Blanda, G., Bendini, A., \& Toschi, T. G. (2011). Characterization of potato flavours: An overview of volatile profiles and analytical procedures. In N. Benkeblia (Vol. Ed.), Potato V. Food: Vol. 5(1), (pp. 1-14). Global Science Books.

Decker, E. A., \& Ferruzzi, M. G. (2013). Innovations in food chemistry and processing to enhance the nutrient profile of the white potato in all forms. Advances in Nutrition, 4 345S-350S. http://dx.doi.org/10.3945/an.112.003574.

EFSA (2015). Scientific opinion on acrylamide in food. EFSA Journal, 13(6), 4104. http:// dx.doi.org/10.2903/j.efsa.2015.4104.

Fukumoto, L. R., \& Mazza, G. (2000). Assessing antioxidant and prooxidant activities of phenolic compounds. Journal of Agricultural and Food Chemistry, 48, 3597-3604. 
http://dx.doi.org/10.1021/jf000220w.

Garayo, J., \& Moreira, R. (2002). Vacuum frying of potato chips. Journal of Food Engineering, 55, 181-191. http://dx.doi.org/10.1016/S0260-8774(02)00062-6.

Gillingham, L. G., Harris-Janz, S., \& Jones, P. J. H. (2011). Dietary monounsaturated fatty acids are protective against metabolic syndrome and cardiovascular disease risk factors. Lipids, 46(3), 209-228. http://dx.doi.org/10.1007/s11745-010-3524-y.

Han, J.-S., Kozukue, N., Young, K.-S., Lee, K.-R., \& Friedman, M. (2004). Distribution of ascorbic acid in potato tubers and in home-processed and commercial potato foods. Journal of Agricultural and Food Chemistry, 52, 6516-6652. http://dx.doi.org/10. 1021/jf0493270.

Hosseini, H., Ghorbani, M., Meshginfar, N., \& Mahoonak, A. S. (2016). A review on frying: Procedure, fat, deterioration progress and health hazards. Journal of the American Oil Chemists' Society, 93, 445-466. http://dx.doi.org/10.1007/s11746-016-2791-z.

ISO 12966-2:2011. (2011). Animal and vegetable fats and oils - Gas chromatography of fatty acid methyl esters - Part 2: Preparation of methyl esters of fatty acid. Geneva.

Kita, A., \& Lisińska, G. (2005). The influence of oil type and frying temperatures on the texture and oil content of French fries. Journal of the Science of Food and Agriculture, 85, 2600-2604. http://dx.doi.org/10.1002/jsfa.2319.

Krokida, M. K., Oreopoulou, V., Maroulis, Z. B., \& Marinos-Kouris, D. (2001). Colour changes during deep fat frying. Journal of Food Engineering, 48(3), 219-225. http:// dx.doi.org/10.1016/S0260-8774(00)00161-8.

Matthäus, B. (2006). Utilization of high-oleic rapeseed oil for deep-fat frying of French fries compared to other commonly used edible oils. European Journal of Lipid Science and Technology, 108, 200-211. http://dx.doi.org/10.1002/ejlt.200500249.

Matthäus, B., \& Haase, N. U. (2014). Acrylamide - Still a matter of concern for fried potato food? European Journal of Lipid Science and Technology, 116(6), 675-687.

Molina-Garcia, L., Santos, C. S. P., Cunha, S. C., Casal, S., \& Fernandes, J. O. (2017). Comparative fingerprint changes of toxic volatiles in low PUFA vegetable oils under deep-frying. Journal of the American Oil Chemists' Society, 94, 271-284.

Molina-Garcia, L., Santos, C. S. P., Melo, A., Fernandes, J. O., Cunha, S. C., \& Casal, S. (2015). Acrylamide in chips and French fries: A novel and simple method using xanthydrol for its GC-MS determination. Food Analytical Methods, 8(6), 1436-1445. http://dx.doi.org/10.1007/s12161-014-0014-5.

Nagata, M., \& Yamashita, I. (1992). Simple method for simultaneous determination of chlorophyll and carotenoids in tomato fruit. Journal of the Japanese Society for Food Science and Technology, 39(10), 925-928.

Nayak, P. K., Dash, U., Rayaguru, K., \& Krishnan, K. R. (2016). Physico-chemical changes during repeated frying of cooked oil: A review. Journal of Food Biochemistry, 40, 371-390. http://dx.doi.org/10.1111/jfbc.12215.

Pedreschi, F. (2012). Frying of potatoes: Physical, chemical, and microstructural changes. Drying Technology, 30(7), 707-725. http://dx.doi.org/10.1080/07373937.2012. 663845.

Pérez-Jiménez, J., Pérez-Jiménez, J., Arranz, S., Tabernero, M., Díaz- Rubio, M. E., Serrano, J., ... Saura-Calixt, F. (2008). Updated methodology to determine antioxidant capacity in plant foods, oils and beverages: Extraction, measurement and expression of results. Food Research International, 41(3), 274-285. http://dx.doi.org/ 10.1016/j.foodres.2007.12.004.
Perkins, E. G. (2007). Volatile odor and flavor components formed in deep frying. In M. D. Erickson (Ed.). Deep frying chemistry, nutrition and practical applications (pp. 51-56). Urbana, IL: AOCS Press.

Regulation (EU) No. 1169/2011 (2011). Official Journal of the European Union, 18-63.

Romano, R., Giordano, A., Vitiello, S., Grottaglie, L., \& Musso, S. S. (2012). Comparison of the frying performance of olive oil and palm superolein. Journal of Food Science, 77(5), C519-C531. http://dx.doi.org/10.1111/j.1750-3841.2012.02663.x.

Salta, F. N., Kalogeropoulos, N., Karavanou, N., \& Andrikopoulos, N. K. (2008). Distribution and retention of phytosterols in frying oils and fried potatoes during repeated deep and pan frying. European Food Research and Technology, 227, 391-400. http://dx.doi.org/10.1007/s00217-007-0733-6.

Santos, C. S. P., Cunha, S. C., \& Casal, S. (2017). Deep or air frying? A comparative study with different vegetable oils. European Journal of Lipid Science and Technology. http:// dx.doi.org/10.1002/ejlt.201600375.

Servili, M., Selvaggini, R., Esposto, S., Taticchi, A., Montedoro, G. F., \& Morozzi, G. (2004). Health and sensory properties of virgin olive oil hydrophilic phenols: Agronomic and technological aspects of production that affect their occurrence in the oil. Journal of Chromatography A, 1054, 113-127 DOI: 10/1016/ j.chroma.2004.08.070.

Troncoso, E., Pedreschi, F., \& Zíniiga, R. N. (2009). Comparative study of physical and sensory properties of pre-treated potato slices during vacuum and atmospheric frying LWT - Food Science and Technology, 42, 187-195. http://dx.doi.org/10.1016/j.lwt. 2008.05.013.

Tseng, Y.-C., Moreira, R., \& Sun, X. (1996). Total frying-use time effects on soybean-oil deterioration and on tortilla chip quality. International Journal of Food Science and Technology, 31, 287-294.

van Loon, W. A. M., Linssen, J. P. H., Legger, A., Posthumus, M. A., \& Voragen, A. G. J. (2005). Identification and olfactometry of French fries flavour extracted at mouth conditions. Food Chemistry, 90(3), 417-425. http://dx.doi.org/10.1016/j.foodchem. 2004.05.005.

Wu, T., Yan, J., Liu, R., Marcone, M. F., Aisa, H. A., \& Tsao, R. (2012). Optimization of microwave-assisted extraction of phenolics from potato and its downstream waste using orthogonal array design. Food Chemistry, 133, 1292-1298. http://dx.doi.org/ 10.1016/j.foodchem.2011.08.002.

Yost, M., Abu-Ali, J. M., \& Barringer, S. A. (2006). Kinetics of potato color and texture development during baking, frying, and microwaving with the addition of liquid smoke. Journal of Food Science, 71, E364-E369. http://dx.doi.org/10.1111/j.17503841.2006.00171.x.

Zhang, H., Zhang, H., Cheng, L., Wang, L., \& Qian, H. (2015). Influence of deep-frying using various commercial oils on acrylamide formation in French fries. Food Additives \& Contaminants: Part A, 32(7), 1083-1088. http://dx.doi.org/10.1080/ 19440049.2015.1045559.

Ziaiifar, A. M., Achir, N., Courtois, F., Trezzani, I., \& Trystra, G. (2008). Review of mechanisms, conditions, and factors involved in the oil uptake phenomenon during the deep-fat frying process. International Journal of Food Science and Technology, 43, 1410-1423. http://dx.doi.org/10.1111/j.1365-2621.2007.01664.x. 